Scottish Government and Politics 
For James Kellas 


\section{Scottish Government and Politics}

An Introduction

Peter Lynch

Edinburgh University Press 
(C) Peter Lynch, 2001

Edinburgh University Press Ltd 22 George Square, Edinburgh

Typeset in 11 on 13pt Goudy by Hewer Text Ltd, Edinburgh, and printed and bound in Great Britain by MPG Books Ltd, Bodmin

A CIP Record for this book is available from the British Library

ISBN 0748612874 (paperback)

The right of Peter Lynch

to be identified as author of this work has been asserted in accordance with the Copyright, Designs and Patents Act 1988. 